\title{
Making Learners Pragmatically Competent
}

\author{
Dr. Roy Pushpavilasam Veettil \\ Assistant Professor of English \\ Sohar University
}

\section{Introduction}

Globalization has brought the world together in an unprecedented way leading to the inevitability of a lingua franca for the world. So far, this role has been well played by the English language. However, the emergence of what has come to be known as World Englishes has resulted in certain pitfalls in effective communication. This happens at various linguistic levels such as lexical level, grammatical level, phonological level and discourse level.

Every language is intimately bound to the culture it represents. Though English has taken up the role of an international language, it is inadequate to represent all the cultures wherein it is used either as a second language or as a foreign language. Therefore, English has been nativized in several ways to make it suitable to carry the cultural weight of the lands to which it has been transplanted. Thus, a knowledge of English at segmental and suprasegmental level alone is not enough if one is to succeed on international platforms. It also demands pragmatic competence.

This paper is an attempt to highlight the necessity of making the learners aware of the varying pragmatics and the ways in which they affect intelligibility.

\section{Pragmatics and Intelligibility}

The dynamics of communication is not the same in all the communities. That is why language is said to have both communicative and communal values. Verbal and nonverbal communications vary from culture to culture. What is accepted and appropriate in one culture can be highly offensive in another. The adoption of English by the various world communities has resulted in a lot of sociolinguistic and pragmatic transfers to English. That is to say, the rules and styles of the mother tongue of a speech community are also applied to English. It is not always an unconscious activity. Some transfers are intentional. They are attempts to make English suitable to the new socio cultural context to which it has been transplanted. Such experiments, as Patil (2008) maintains, are necessary because the culture specific speech acts of different linguistic communities cannot be explained adequately using the framework of monolithic English pragmatics (pp. 37-38). In fact, pragmatics varies even among the inner circle countries. Unawareness of the pragmatics of both verbal and nonverbal communications can lead to misunderstandings.

Sharma (2011) illustrates this by citing a very unpleasant experience George Bush senior, the former president of America, had during one of his visits to Australia in 1992. After boasting of his expertise in hand gestures, he gave the ' $\mathrm{V}$ ' for victory sign and drove off in his limousine in Canberra. The enraged spectators gave back the same signal to the president. Bush came to know only later that in Australia the 'V signal' (the way he showed it) has the same vulgar meaning as the middle finger gesture in America. He had to apologise for his blunder though it was committed unknowingly (pp. 3-4).

Gestures form a large part of nonverbal communication. There are cross-cultural differences in the meanings of gestures. In addition, body movements, the way of sitting, eye contact, the space between the interlocutors, the posture and the body movements can suggest a lot. The problem, when it comes to international and sometimes even intranational communication is that all the above-mentioned nonverbal aspects of communication have different meanings in different communities.

Morries et al. (1979) give another example of pressing the forefinger against the cheek and then rotating it as if screwing something into ones face. This gesture is used in many countries such as Greece, Spain and Germany. However, it conveys different meanings in those countries. In Italy, it is a sign of appreciation, especially of food. 
In southern Spain, it is used to signal that someone is effeminate in a derogatory sense. In Germany, it means, "you are crazy". Not all Europeans, let alone Africans and Asians (as cited in Brown, 1989) know these meanings. Thus, this gesture is eminently misinterpretable or uninterpretable.

Eye movements mean a lot in many cultures. Looking into someone's eye is considered rude in America whereas looking away from the other's face is a sign of insincerity in India. Indians expect people to look at the face and talk. Maintaining a longer eye contact is taken as a sign of superiority. A direct and open stare elicits a feeling of trust in India (Sharma, 2011). There are hundreds of such nonverbal acts in every community. In the present day context of international mingling in the various arenas of life, an awareness of the different ways of nonverbal communication is necessary for successful communication.

There are also marked differences in verbal communications due to the sociolinguistic and pragmatic transfers mentioned above. Verbal communications do not always involve words. There are non-lexical paralinguistic aspects such as inflections, pacing, intensity, tone etc. All these features can add meanings to words as they determine how words are used in communication. The truth in every communication is that how something is uttered is more important than what is said. For example, the use of the word 'please' in 'Please get out of here' usually does not make it a request. The variations in the abovementioned paralinguistic aspects have different connotations in different cultures. When those cultural nuances are transferred to English and used in intercommunal communications, there can be misinterpretations.

A study, done by Gumperz (1982), manifests this clearly. His study was initiated by the many complaints of the airport staff at Heathrow airport. Their complaint was that the Indian and Pakistani employees at the cafeteria were rude in their behaviour to the customers. To know what exactly was going on, Gumperz taped their talk on the job. He found that the misunderstanding was caused by the tiny difference in intonation. When a British lady requested for meat, the Asian server wanted to know whether she wanted gravy on it. The British lady asked 'Gravy?' and the Asian server repeated 'Gravy' with a falling intonation instead of rising. Later when the tape was played to Asians and British, the Asian listeners could not find anything odd in the conversation. However, the British listeners found it rude. To the British, 'Gravy?' with a question intonation means 'would you like gravy?' But, the same word if spoken with a falling intonation, as in the case of the Asian server, means 'This is gravy. Take it or leave it' (as cited in Tannen, 1984, p. 192). Certainly, the East is East and the West is West. Even intonational differences can lead to miscommunication. Gumperz also pointed out another difference between the Indian speakers and the British speakers. The Indian speaker emphasizes the sentence preceding the main point and says the main point in a low voice to achieve some dramatic effect. However, the British speaker emphasizes the main point itself. The danger here is that the British listener might take the emphasized sentence as the main point (as cited in Tannen, 1984, p. 194). In addition, Indians speak loudly to get the attention of the listener or to win the floor. Speaking loudly can be interpreted as a sign of anger in the western culture.

Similarly, there are important differences in the way speech acts are performed in different cultures. For example, greetings in Arabic consist of a long list of questions after the initial 'aslamu aleikum'. The questions range from enquiries about one's personal wellbeing to the wellbeing of the members of the family including the domestic animals at times. However, all these are not transferred to English though they cannot avoid asking about one's health and the health of the members of the family. A voluntary offer of help for anything is also a part of the greeting. Kaplan (1996) points out a specific feature of argumentation in Arabic. Arab learners do not develop an argument as the Americans do. They argue by accretion and repetition. They highlight and repeat the main point instead of building up to it. To the Americans that is not an argument at all (as cited in Tannen, 1984, p. 194).Another deviation at the speech act level is in complementing. As in Indian English, Arab learners of English tend to minimize self-praise and maximize the praise of the other. They exchange multiple versions of certain speech acts such as that of congratulating in 'elf mabrook' (thousand congratulations), wishing good health/safety in 'elf salamaat' (thousand safeties), etc., as they do in Arabic. These are deviant discourse features of Arab variety of English, which may cause cross-cultural pragmatic errors in communication.

There are many stylistic deviations in the nativized varieties. They mainly aim at cultural suitability. Parashar (1994) has listed a few such examples from Indian English.

Kindly advise me please.

I respectfully submit the following few lines for favour of your kind consideration.

With due respect I beg to inform you.

I have the honour to invite a reference to your letter. 
I need some esteemed help.

These stylistic deviations from the native speaker norms are acceptable and appropriate in the Indian variety of English. However, the native speaker groups involved in Parashar's study found them to be over polite (p. 163).

Tannen (1984) and Patil (2008) talk of some deviations in the Japanese variety. In the Japanese culture, complimenting involves several exchanges of praise and ritual denials. Japanese cannot accept a compliment merely by saying 'Thank you'. He has to deny all the praises showered on him and return bouquets of praises to the one who complimented him/her. This may cause confusion and embarrassment to westerners who are known for their straightness and brevity. The western brevity and the Japanese prolixity are at the two extremes. Similarly, Japanese culture values group harmony, and thus, Japanese people avoid disagreements. Their over politeness does not allow them to say 'no'. One must understand the meaning of their 'yes' from the way they say it. If the Japanese have only the positive response 'yes', Indians have both 'yes' and 'no'. However, they have their own meanings of these words. Ma (1996) makes an interesting observation. A General Motors manager was confused and frustrated over a conversation with his Asian clients. He is reported to have said; "I don't understand you Asians. You say 'no' when you are supposed to say 'yes', and 'yes' when you are supposed to say 'no' (as cited in Patil, 2008, p. 38).

Sanyal's (2006) study on Indian English brings out many obfuscating stylistic features of Indian English writing. She finds that Indians still have a tendency to cling to literary Victorian English, which later Victorians rejected. Instead of being direct and simple, many writers write to impress rather than to inform. She calls this 'the whirligig of circumlocution' (p. 14). She finds fault with ill-arranged parenthetical clauses and many other devices that make things incomprehensible or at least difficult to comprehend. The following is one of her examples:

In this day and age, it is unheard that a civilized country should target a city with a population of 650,000 and little in the way of military installations, with three major sorties involving 800 planes which sent down hundreds of tons of incendiary bombs that killed 35,000 people, largely civilians, and caused Dresden, a most beautiful city, to burn for seven days and seven nights (p.11).

She breaks up the same text in the following manner to show how foggy and obfuscating the original text was: It is barbaric that a country should seek to destroy a city with few military installations and 650,000 people. After three sorties by 800 planes had rained hundreds of tons of incendiary bombs, beautiful Dresden burnt for seven days and seven nights. The death toll was 35,000- mostly civilians (p. 11).

As Bhargava (2011) criticizes, “...the trouble arises when our people strive after effect while using English. The desire to impress is the bane of the writing/speaking of many of us" (p. 4).The message is often lost in such pompous attempts. Simplicity is mistaken as inefficiency in language.

Idiomatic expressions are also a threat to intelligibility. To give a simple example, in some parts of England, during an informal conversation a man may ask his friend, "How is your strife and struggle?" Even for many native speakers of English this is all Greek. It is unintelligible. The real meaning is "How is your wife?"

Language is not used the same way in all the communities. As Patil (2008) maintains, different cultures have different ways of doing things with words (pp. 37-38). When such socio linguistic features, which are typical of one culture, are transferred to the nativized varieties of the second language, intelligibility is at stake unless the interlocutors are familiar with them.

\section{Familiarising learners with varying pragmatics}

As discussed above, pragmatics varies from culture to culture and English is inadequate to represent all the cultures across the world where English is used as a first language or a second language or a foreign language. Even native speaker countries do not share the same cultural context and pragmatics. Communicative competence in the present global situation demands that one becomes aware of the social, cultural and discourse conventions thought to be appropriate in different contexts. As Harling and Taylor (2003), point out grammatical errors may be condoned as incompetence in the target language but not pragmatic differences.

A pragmatic error may hinder good communication between speakers, may make the speaker appear abrupt or brusque in social interactions, or may make the speaker appear rude or uncaring. Unintentional insults to interlocutors and denial of requests have been identified as other potential pragmatic hazards (p.38). 
Despite the increasing need for making the learners pragmatically competent, this aspect of language/learning/teaching has been neglected in most English language teaching/learning programmes. A close observation of many English Language learning course books bears testimony to this. It is to be noted that teaching pragmatics should not aim at making the learners emulate the pragmatics of any native speaker countries because as mentioned above pragmatics vary from culture to culture even in countries where English is the first language. The goal should be to make the learners aware of the varying pragmatics and to enable her/him to choose the one suitable according to what the context demands.

Competence, be it linguistic or communicative, cannot be taught. Rather, it is something to be acquired. However, as Kasper(1997) opines learners can be provided with opportunities to develop their competence in pragmatics (p.1).One suggested way to help learners raise their awareness of pragmatics is to make them compare the performance of speech acts in their first language with the performance of the same speech acts in the target language and vice versa. Edwards and Csizer (2003) give the example of effectively using a dialogue literally translated from Hungarian to English to highlight the differences in the speech acts of opening and closing conversations. They could successfully make the learners aware of how openings and closings differed in both the languages. For example, 'How are you?', though in form is an interrogative sentence, functions as a greeting in English. However, in Hungarian it is a real question indicating genuine interest in the well-being of the other person. Naturally, one responds to this question with a description of his/her health condition or any other such issues. Similarly, a conversation in Hungarian ends with 'hello'. Quite contrary to English, it performs the speech act of leave taking in Hungarian (p.18). A teacher may choose translations from the learners' first language depending on the speech act he/she would like to focus on.

They may also be introduced to speech acts as performed in various cultures across the globe and asked to identify what speech acts they are. For example, the teacher may give the following passages to the students and ask them to discuss what it means to them;

1. She pressed her forefinger against the cheek and then rotated it as if screwing something into her face.

After eliciting from the learners the meanings they derive from the passage they teacher can bring to their notice what this means in Italy, Spain and Germany.

2. May you always wear red!

This, in fact, is an Indian way in which a grandparent blesses her granddaughter at the time of her weddings. The prayer here is that she should not become a widow or that she should be blessed by gods to have a very long marital life.

3. We are really sorry that you had to do the dishes. We are also sorry that we took a lot of time here.

This, in Japanese, is a way of thanksgiving to a host at the end of a party.

4. Where are you going?

In the Dravidian language Malayalam, this is a greeting and not a question.

5. Shall I come then?

This is an expression of leave taking in Malayalam.

6. On my head

This is the literal translation of the Arabic expression 'al rasi'. This is a way of responding to someone who demands something.

All the pragmatic differences such as the Japanese 'yes', over-politeness found in Indian English, the Arab way of complimenting etc. can be introduced to the learners in a similar way.

Yet another way is to reverse the above-suggested activity. The teacher can present a situation and ask the learners to think about how people from different cultural and linguistic background would react to that. For example, they may be given the following situation;

A mother is advised by her friend to be careful about her daughter as she was seen walking hand in hand with a young boy on the banks of a river. How, do you think, the mother will react to this when the daughter reaches home that evening from work or college? The teacher can ask the students to think of the reactions of an American mother and an Indian mother. The differences in their reactions will also throw light on the pragmatic differences as well (adapted from Thakoor, Pp. 181-82). 


\section{Conclusion}

Communication between communities of varying cultural and linguistic backgrounds has become an inevitability of the day. However, linguistic competence alone cannot guarantee success in communication. It also demands communicative competence, which can be achieved only if the interlocutor is aware of the appropriate way of performing varying speech acts in varying cultures. This can be ensured only by making the learners aware of the inadequacy of English for universal pragmatics and by exposing them to the unique ways of performing the same speech acts in different cultures. Needless to say, there is a dire need to include pragmatics in course books for language learning/teaching.

\section{References}

Arabic words that have no English equivalents. Retrieved fromon 8the April. 2017 http://www.barakabits. com /2014/07/5 -arabic-words-english-equivalent

Bhargava, S. (2011). Glocalisation of English studies in the context of globalisation. In Tarun

Patel (ed). ELT Weekly, Issue \#104. Retrieved on Nov.15, 2011 from http://www.elt eekly.com/elt.newsletter

Brown, A. (1989). Some thoughts on intelligibility. The EnglishTeacher,vol XV111.1-6 Sept. 1989. Retrieved on Oct. 29,2011fromhttp://www.melta.Org.my/ET/1989/main4 html.

Edwards,M \& Csizer,K (2004). Developing pragmatic competence in the EFL classroom. In

Koller, M (ed.).Forum. volume 42, No. 3 .Pp.16-21

Gumperz.J.J.(1982). Discourse strategies,Cambridge: Cambridge University Press

Harling, K.B\& Taylor,R.M (2003). Introduction to teaching pragmatics. In Anker,W.P (ed.) Forum. Volume 41, No.3 Pp. 37-43

Kaplan. R.(1966). Cultural thought patterns in intercultural education. Language learning. $\quad$ Vol.16. 1-20

Ma. R. (1996). Saying 'Yes' for 'no' and 'no' for'yes': A Chinese rule. Journal of Pragmatics,25,257-266

Parasher, S.V. (1994). Indian English: certain grammatical lexical and stylistic features. In Agnihotri, R.K and A.L. Khanna (eds.) Second Language Acquisition:Sociocultural andLinguistic Aspects of English in India, pp.145-64, New Delhi: Sage Publications

Patil, Z.N. (2008). On the nature and role of English in Asia. Journal of English as an International Language. Volume 1, 25-47. Retrieved on March 19, 2009 from http:// www.journal of English as an international language

Sanyal.J. (2006) Indlish:The book for Every English-speaking Indian, New Delhi: Viva Books

Sharma, N. (2011). Contribution of nonverbal language in communication: A Study of non- verbal communication. In Tarun, P.(ed.) ELT Weekly vol.3 Issue 107

Tannen, D. (1984). The pragmatics of cross-cultural communication. In Applied Linguistics. $\quad$ Vol.5,No.3, $189-95$ 